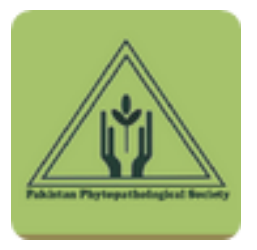

$$
\text { Pakistan Journal of Phytopathology }
$$

\title{
CHARACTERIZATION AND PATHOGENICITY OF FUSARIUM PROLIFERATUM ON DATE PALMS IN ALGERIA.
}

\author{
a,bSafia Sahouli*, cJose Sanchez, cEduardo Gallego, aAminata O. E. H. Khelil \\ a Laboratory of Protection of Ecosystems in Arid and Semi-arid Area, University Kasdi Merbah Ouargla.Ouargla, DZ 30000. \\ ${ }^{b}$ Department of Biology, Faculty of Natural and Life Sciences Ziane Achour. University of Djelfa Djelfa, DZ 17000. \\ ${ }^{c}$ Botany Unit, Department of Biology and Geology, University of Almeria,E- 04120 Almeria, Spain.
}

\begin{abstract}
A B S T R A C T
During a survey conducted from 2013-2014, in order to determine the fungal agents of wilt and dieback of date palms (Phoenix dactylifera L.) from Ghardaia province in Southern Algeria, two Fusarium species; Fusarium oxysporum, Fusarium proliferatum and Thielaviopsis sp were identified based on their cultural and morphological characteristics. Fusarium proliferatum (Matsush.) Nirenberg ex Gerlach \& Nirenberg was isolated and identified, and Koch's postulates were completed. Morphological identification was based on morphological characteristics on PDA and SNA culture media, and it was confirmed molecularly using ribosomal DNA sequence. Data comparison of the sequence (KR 856363) at GenBank revealed $100 \%$ similarity to this fungal species. A phytopathogenicity test was carried out with 3 months old plants, and they were inoculated by dipping the roots into a fungal conidial suspension and also compared with Fusarium oxysporum f. sp. albedinis (Kill. \& Maire) Malençon, known causal agent of date palm Fusarium wilt (Bayoud disease). After 90 days, disease incidence was eventually $76.66 \%$ and $80 \%$ for $F$. proliferatum and $F$. oxysporum, respectively, and the calculus of the index shows that this fungus would be a very serious threat to date palm. Microscopic observation of the roots provided confirmatory evidence that $F$ proliferatum is causing a vascular disease on date palm.
\end{abstract}

Keywords: Phoenix dactylifera, Fusarium proliferatum, pathogenicity, Fusarium wilt, Microscopic observation.

\section{INTRODUCTION}

Date palm (Phoenix dactylifera L.) is one of the most fruit crops in the arid regions of the, North Africa and the Middle East (Chao and Krueger, 2007).

Date palm is affected by many diseases, bayoud remains the most serious one. It is caused by a soil born pathogen, Fusarium oxyspurum f .sp. albedinis (Djerbi, 1998).

The Bayoud disease caused by Fusarium oxysporum f. sp. albedinis of the date palm tree is one of the most dangerous diseases in the world (Sedra, 2010). This disease was first reported from Morocco in 1870.The

\begin{tabular}{l} 
Submitted: January 28, 2020 \\
Revised: May 20, 2020 \\
Accepted for Publication: June 04, 2020 \\
* Corresponding Author: \\
Email: sahoulibio@gmail.com \\
(c) 2017 Pak. J. Phytopathol. All rights reserved. \\
\hline
\end{tabular}

name "bayoud" is derived from the Arabic (abiadh) meaning white, and is a reference to the whitish discoloration of diseased fronds (Zaid et al., 2002).

Fusarium oxysporum Schltdl belongs to the Elegans section (Gerlach and Nirenberg, 1983) and is the most common species, causes vascular wilt on many different plant species (DiPietro et al., 2003). A serious disease of date palm was reported caused by $F$. solani showed wilt and decline the disease occurred in date palm of Iraq and Iran(Sarhan, 2001; Mansoori and Kord, 2006) several studies reported that Fusarium oxysporum, $F$. moniliforme, $F$. proliferatum, and $F$. solani to be associated with Date Palm Sudden Decline in different parts of the world (Sarhan, 2001;Abdullah, 2010; Alwahshi et al., 2019).

Fusarium proliferatum (Matsush.) Nirenberg ex Gerlach \& Nirenberg belongs to the Liseola section of Fusarium. It is a common pathogen infecting numerous crop plants 
and occurring in various climatic zones (Stepien et al., 2011), Fusarium proliferatum is a world-wide occurres saprophytic fungi, also known to be a pathogen of many economically important plants (Tamburini, 2016) Fusarium proliferatum is not host specific and can infect a wide range of plant hosts (Masratul Hawa et al.,2013). And is a causal agent of Fusarium crown and root rot of Asparagus (Logrieco et al., 1998) date palm (Abdalla et al., 2000) and ornamental palms (Armengol et al., 2005)This species is considered as the most common maize pathogen, as well as the most effective producer of the polyketide-derived fumonisin mycotoxins (Stepien $e t$ al.,2011). )

\section{MATERIALS AND METHODS}

Isolation and morphological identification: The study was conducted during 2013-2014 to determine the fungal agents of wilting and dieback of the date palms (Phoenix dactylifera L.), from Ghardaia province in Southern Algeria. For this purpose, 20 samples of symptomatic rachis were collected from 14 localities and seven palm tree with wilting symptoms (yellowish to pinkish) discoloration and brownish spots in diseased leaves in a palm plantation in Boulila Oasis.

The samples were immediately surface sterilized in alcohol for $5 \mathrm{~min}$, rinsed three times in sterilized distilled water (SDW), and placed in a Petri dish with Potato Dextrose Agar (PDA)

then incubated in BOD for 7 days at $25^{\circ} \mathrm{C}$.

After 7 days, a pure culture obtained from an isolate's single spore was grown on PDA to study the colony morphology and pigmentation, on Synthetic NutrientPoor Agar (SNA) medium contained 1.0g KH 2 PO $4,1.0 \mathrm{~g}$ KNO $3,0.5 \mathrm{~g}$ MgSO $4.7 \mathrm{H} 2$ 0, 0.5g KCl, $0.2 \mathrm{~g}$ glucose, $0.2 \mathrm{~g}$ sucrose, and $20 \mathrm{~g}$ agar in one litre of distilled water (Nirenberg, 1981) to study the shape, size and type of macroconidia, and on $\mathrm{KCl}$ medium ( $8 \mathrm{~g} \mathrm{KCl}$; $14 \mathrm{~g}$ agar/L) to stimulate formation of microconidia into chains. These Petri dishes were kept at room temperature (22$24{ }^{\circ} \mathrm{C}$ ) under black light for 10 days, and the aerial mycelium was microscopically examined.

\section{Molecular identification}

DNA extraction: DNA was extracted from the isolate. PDA-grown 7-days-old mycelium was scraped directly from agar plates and ground to a fine powder in liquid nitrogen using a sterile pistil. Total DNA was extracted using the EZNA fungal DNA mini Kit (OMEGA bio-tek), according to the manufacturer's instructions.

PCR amplification of ribosomal DNA (rDNA): PCRs were conducted in $25-\mu \mathrm{l}$ reaction volumes. Each reaction tube contained approximately $5 \mu \mathrm{L}$ DNA template, $5 \mu \mathrm{l}$ $5 \times$ of PCR buffer, $6.66 \mu \mathrm{L}$ SDW, $0.64 \mu \mathrm{L}$ (each) of $10 \mathrm{mM}$ dntp's, $1.5 \mu \mathrm{L} 25 \mathrm{mM} \mathrm{MgCl} 2,3 \mu \mathrm{l}$ each of $2 \mu \mathrm{M}$ forward and reverse primers ITS1 and ITS4, and $0.2 \mu \mathrm{l}$ Taq polymerase $(5 \mathrm{U} / \mu \mathrm{L})$. The thermal cycling parameters were initial denaturation at $94{ }^{\circ} \mathrm{C}$ for 5 min followed by 35 cycles consisting of denaturation at $95{ }^{\circ} \mathrm{C}$ for $30 \mathrm{~s}$, annealing at $50{ }^{\circ} \mathrm{C}$ for $1 \mathrm{~min}$, and extension at $72{ }^{\circ} \mathrm{C}$ for 1 min. A final extension at $72{ }^{\circ} \mathrm{C}$ for $7 \mathrm{~min}$ was done at the end of the amplification.

The nuclear rDNA region of the internal transcribed spacers (ITS), including the 5.8S rDNA, was amplified with the universal primers ITS 1 (5' TCCGTAGGTGAACCTGCGG $\left.3^{\prime}\right)$ and ITS 4 (5' TCCTCCGCTTATTGATATGC $3^{\prime}$ ) as described by White et al., (1990).

The amplification was analyzed in agarose gel at $1 \%$ through electrophoresis. PCR resulting product was purified using Invitrogen PureLink ${ }^{\circledR}$ Quick Gel Extraction and PCR Purification Combo Kit, sequenced in two directions (5' to $3^{\prime}$ and $3^{\prime}$ to $5^{\prime}$ ) with automatic sequencer.

Base pairs obtained were compared with the sequences reported in the database of NCBI's Genbank (National Center for Biotechnology Information, www.ncbi.nih.) with the highest scores (more than $98 \%$ of similarity and coverage)).

Pathogenicity test: Pathogenicity testing of pure cultures used methods for diagnosis of bayoud disease of date palm (caused by Fusarium oxysporum f. sp. albedinis). Pathogenicity tests were conducted using Koch's postulates to confirm the Fusarium species as the cause of Fusarium wilt. Seeds of the variety Deglet Nour were used, which is susceptible to all known pathogenic isolates of Fusarium oxysporum f. sp. albedinis (Pereau-Leroy,1958; Louvet and Bulit,1972; Saaidi, 1979). They were surface disinfected with $1 \%$ sodium hypochlorite $(\mathrm{NaOCl})$ for $10 \mathrm{~min}$, then three times washing with sterilized water and pregerminated in Petri dishes with sterile blotting paper at room. Germinated seeds were transferred into a long tube sterile $(25 \mathrm{X} 150 \mathrm{~mm})$ on the surface of $25 \mathrm{ml}$ Knop nutrient medium to promote growth of the plant in a growth chamber at $28^{\circ} \mathrm{C} / 25^{\circ} \mathrm{C}$ with $16-\mathrm{h}$.

In this experiment, one isolate of Fusarium proliferatum (F15) previously purified from sample tissue and one isolate of Fusarium oxysporum f.sp. albedinis (F60) source INPV of Ghardaia (Algeria) were tested for their 
phytopathogenicity. The inoculum of strains was prepared by flooding the agar surface with $10 \mathrm{ml}$ SDW, the filtrate was diluted and the conidial concentration

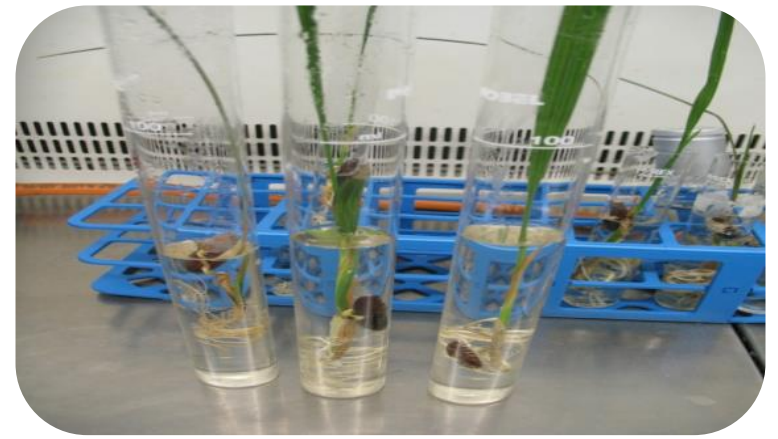

A

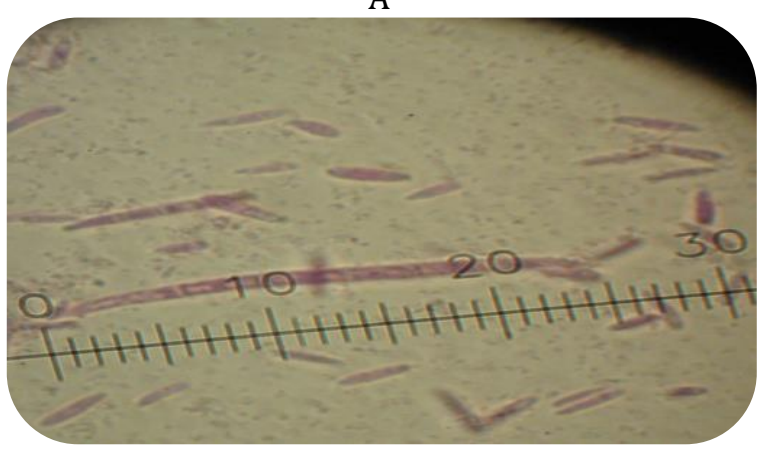

C

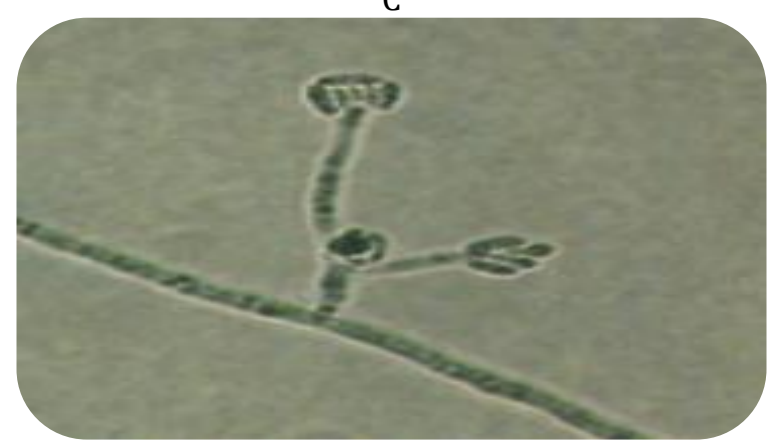

E was adjusted to $10^{6}$ conidia/mL with a hemocytometer. This solution was used for the root dip inoculation procedure (Figure1 A).

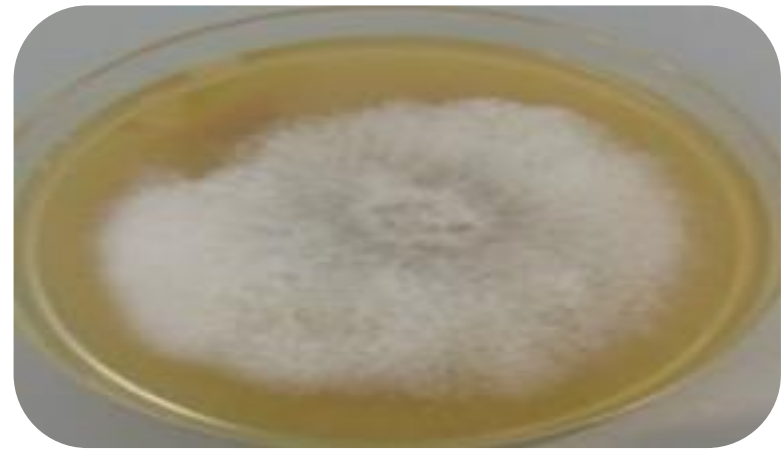

B

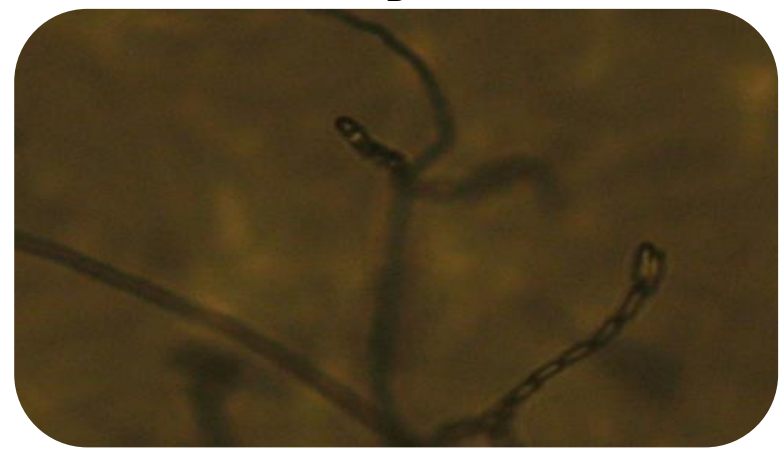

D

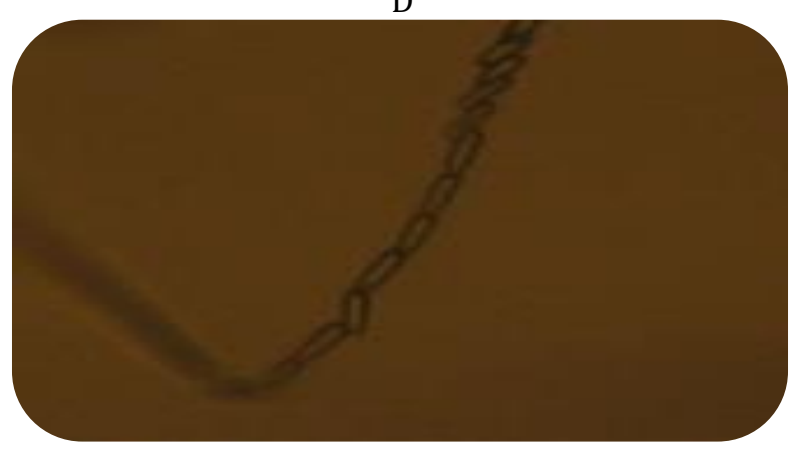

F

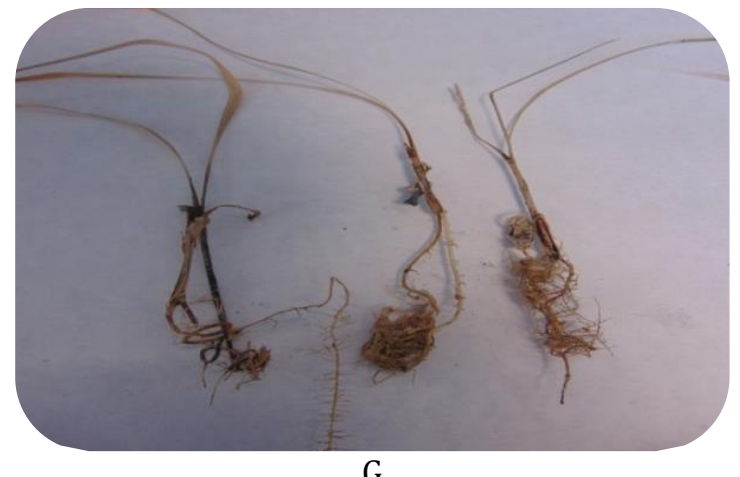

G

Figure1. Pictures and light micrographs (x 400) of Fusarium proliferatum. A, the root dip inoculation procedure by $F$ proliferatum. B, PDA colony growth; C, micro and macroconidia; D, microconidia in chain; E, phialides and microconidia grouped in false heads; F, conidiophores; G, inoculated plants 
The technique of inoculation used described by Luongo et al., (2014), when the plants reached the appropriate stage they were gently washed in sterile water, pruned by removing about $1-2 \mathrm{~cm}$ of the root length and inoculated by root dipping for $20 \mathrm{~min}$ into $30 \mathrm{ml}$ of the conidial suspension. Control plants were root dipped in SDW. Each inoculation was repeated three times and 10 replicate plants were included per treatment. The plants were maintained in a controlled environment growth chamber at $28{ }^{\circ} \mathrm{C} / 25^{\circ} \mathrm{C}$ with 16 -h photoperiod and observed daily for disease progression. Fungal colonies were re-isolated from necrotic plant tissues, and examined to confirm the identity of the pathogen.

Disease incidence (DI) indicates the proportion or percentage of plants diseased within a sampling unit (Seem, 1984). It is calculated by dividing the number of affected plants by the total number of plants.

Disease rating was determined 4 months after inoculation. Individual plants were rated on a scale from 1 to 5 according to visible symptoms on each seedling, where $1=$ no symptoms; $2=$ yellowing or wilting of $1 / 3$ of the plant; $3=$ yellowing or wilting of $2 / 3$ of the plant; $4=$ yellowing and wilting of the whole plant; $5=$ plant dead.

To estimate the severity of the disease, the Disease Severity Index (DSI) was calculated, according El Aoufir (2002), DSI = $\Sigma$ nj $\times$ ij $/ \Sigma j n j$, where, $n=$ number of plants characterized by the index $\mathrm{i}$ of severity of illness attributed to plants. DSI was grouped into classes: $0-1=$ mild disease, $1-2=$ moderately severe disease; $2-3=$ serious disease; $3-4=$ very serious disease. Five plants were collected to perform the microscopic examination.

Statistical analyses were performed using Statistica 6.0 software (StatSoft, USA). The pathogenicity test data were analyzed by one-way ANOVA with multiple comparison procedures (Fisher's LSD method) at $\mathrm{p} \leq$ 0.05 . Student test was used to demonstrate the DSI significantly difference between the two Fusarium species affecting date palm and Pearson's test was used to perform the correlation analyses between DSI and DI, with the statistical level at $\mathrm{p}<0.05$. .

Microscopic observation

Specimens of root for light microscope examination were taken from infected and control plants utilized in the test of pathogenicity. Pieces of root were fixed with $2.5 \%$ glutaraldehyde $\mathrm{pH} 7,4$ in cacodylate buffer for 2 $\mathrm{h}$, and dehydrated in an ethanol series $(50,70,90$, and
$100 \%$ ) for 10 min each. The samples were embedded in EMbed812-ethanol, allowed polymerize in EMbed 812 pure in $60-70 \stackrel{\circ}{\circ}$ for $48 \mathrm{~h}$, Semi thin sections of 0,5 $1 \mu \mathrm{m}$ thickness were made using a microtome and stained with toluidine bleu 0 , the sections were examined under light microscope.

\section{RESULTS}

This fungus was morphologically and molecularly identified as Fusarium proliferatum. Morphologically, PDA colony produces a dense and floccose white aerial mycelium (Figure 1B). Rapidly colony growth and it were sometimes tinged with purple on PDA. Macroconidia are long, slender (Figure1C falcate to almost straight, usually 3-5 septate and thin-walled, measuring: 33 × $3.0 \mu \mathrm{m}$, mostly 24-58 x $2.7 \mu \mathrm{m}$. Chlamydospores were absent. Microconidia were born in chains of varying length in medium $\mathrm{KCl}$ (Figure 1D). The fungi on SNA present false heads were unbranched and branched polyphialides and monophialides (Figure1 E. F).

The Internal transcribed spacer-polymerase chain reaction (ITS- PCR) amplification result 541-bp. Sequence from this study was submitted to the GenBank database (Genbank Accession No. KR856363), these sequencing results were compared to the GenBank database using the NCBI BLAST search program showed $100 \%$ similarity with ITS sequence of $F$. proliferatum (GenBank Accession No. HM 590497).

One week after inoculation with the conidial suspensions, the characteristic symptoms of wilt appeared. Infection in the beginning was typically in the form of yellowing of lower leaves. Roots of the diseased plants showed brownish to blackish lesions. Internal brown discoloration of root tissues was also observed (Figure 1G). F. proliferatum was consistently re-isolated from symptomatic tissues, fulfilling Koch's postulates. No fungi recovered from the control plant. F. proliferatum strain tested and the $F$. oxysporum f.sp. albedinis strain caused the most severe symptoms of the disease, with DI of $76.66 \%$ and $80 \%$, and DSI of 4.5 and 4.6, respectively (Table 1 ).

DSI values from inoculated plants were significantly greater $(\mathrm{p}<0.05)$ than in controls. Test difference between two isolates of Fusarium sp. from DSI analyze did not found any significantly difference; A strong positive correlation between DSI and DI was observed (Figure 2). 
Table 1. Means of disease severity index (DSI) and disease incidence (DI) on 3-month-old seedlings of date palm (Phoenix dactylifera var. Deglet Nour) artificially inoculated with two Fusarium isolates recovered from a date palm.

\begin{tabular}{lll}
\hline & DI & DSI \\
\hline F. proliferatum & $76.66 \pm 5.73 \%$ & $4.5 \pm 0.22^{\mathrm{b}}$ \\
\hline F. oxysporum f.sp. albedinis & $80.00 \pm 10.27 \%$ & $4.6 \pm 0.21^{\mathrm{b}}$ \\
\hline control & $0.08 \pm 0.08 \%$ & $1.2 \pm 0.15^{\mathrm{a}}$ \\
\hline
\end{tabular}

Means with the same letter are not significantly different using LSD Test at $\mathrm{P} \leq 0.05$.

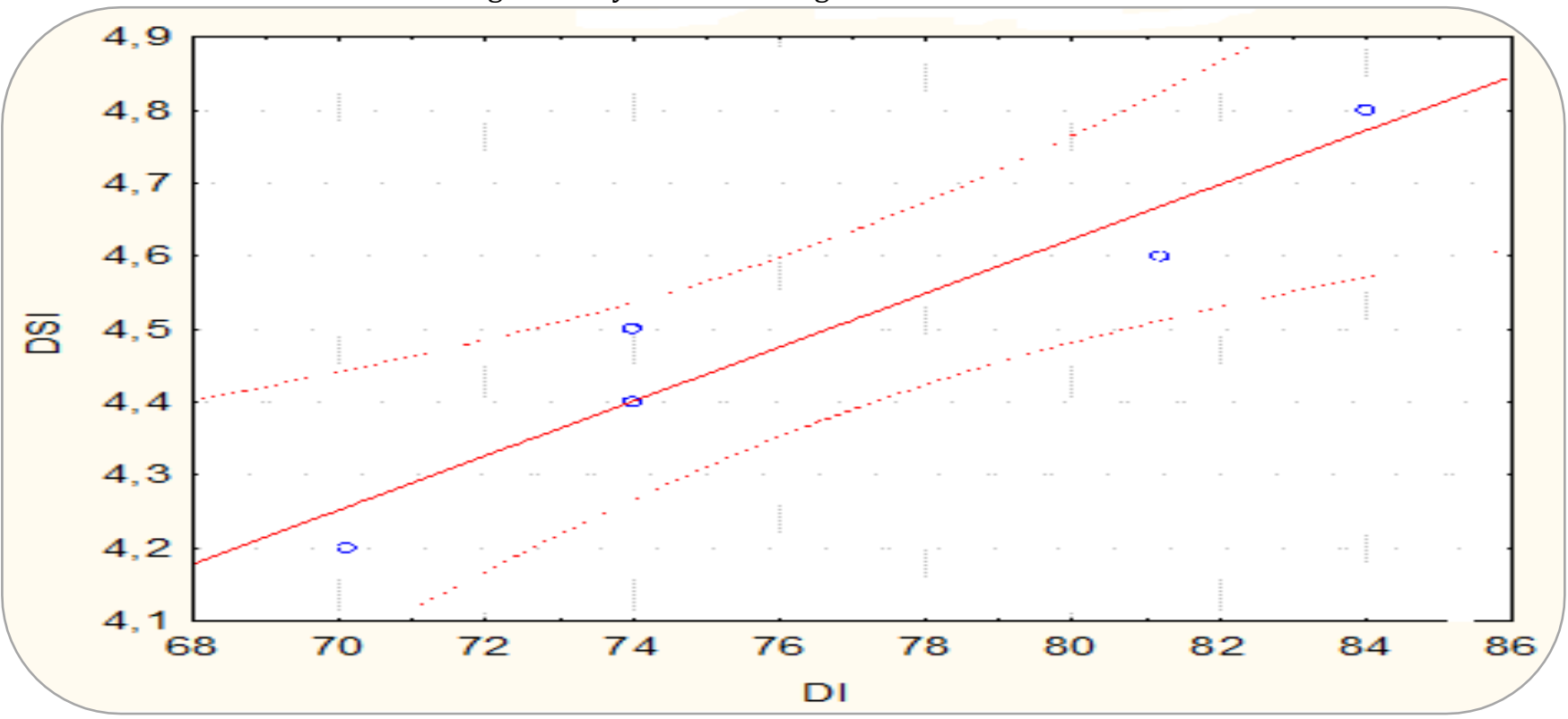

Figure 2. Correlation between the disease severity index and disease incidence of date palm infected by Fusarium proliferatum. $(r=0.95$, DSI $=0,371 \mathrm{DI}+1,653)$.

Transverse section of infected root showed the macroconidia of Fusarium proliferatum present in the xylem cells and is observed and gum deposition in the xylem vessels of tissues prepared from diseased seedlings No gum deposition was observed in healthy tissues (Figure 3).

\section{DISCUSSION}

F. proliferatum, resemble $F$. oxysporum on PDA and can be frequently confused with this species but $F$. proliferatum is characterized by the presence of microconidia in chains on polyphialides and Chlamydospores are absent (Leslie and Summerell, 2006).

Morphological characteristics of the isolate coincide with the reports of Nelson et al., (1983), who mentioned that microconidia are formed in chains on polyphialides, and the presence of polyphialides separates F. proliferatum from Fusarium moniliforme. The chains of $F$. proliferatum on the polyphialides often appear in the shape of a ' $\mathrm{V}$ ' under the lowpower objective of the microscope. Chlamydospores are absent.

Regions of rDNA are commonly used for identification and to infer phylogenetic relationships among fungal species (Lindner and Banik, 2011) likewise,ITS region provides a sufficient genetic to detect and reliably differentiate Fusarium spp cause ocular infections (Oechsler et al., 2009).

Shahnazi et al., (2012) reported that after amplification with ITS1 and ITS4, F solani and $F$. proliferatum were identified, and their morphological identification confirmed.

The results of phytopathogenicity test also corroborate to those reported in Saudi Arabia according Abdalla et al., (2000) who isolated $F$ proliferatum from infected leaves and roots of date palm trees and showed similar symptoms to those caused by $F$. oxysporum f. sp. According Armengol et al., (2005) the pathogenicity tests on Phoenix dactylifera and Phoenix canariensis seedling showed that $F$ proliferatum should be regarded as potentially dangerous pathogen of ornamental palms in Spain. Saleh et al., 2016 also proved that $F$. proliferatum had the highest virulence on date palm leaflets, followed by $F$ solani. 


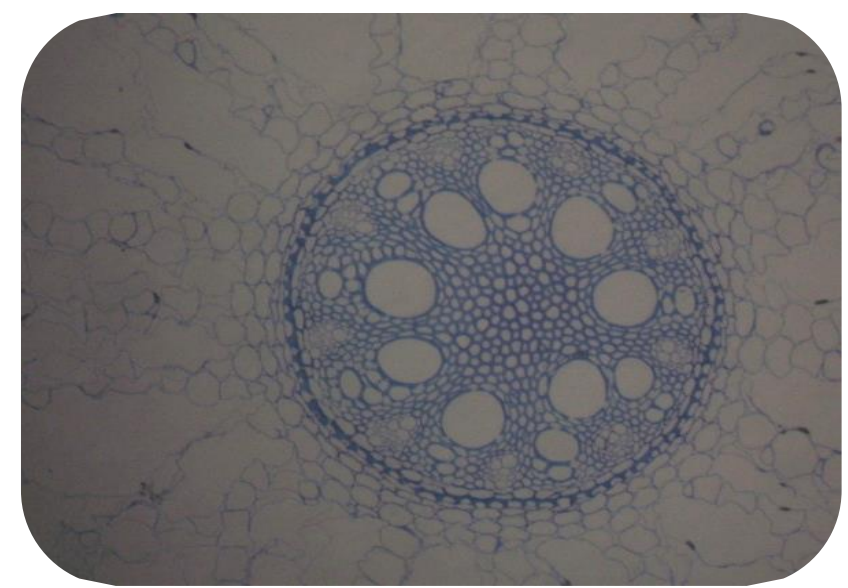

A

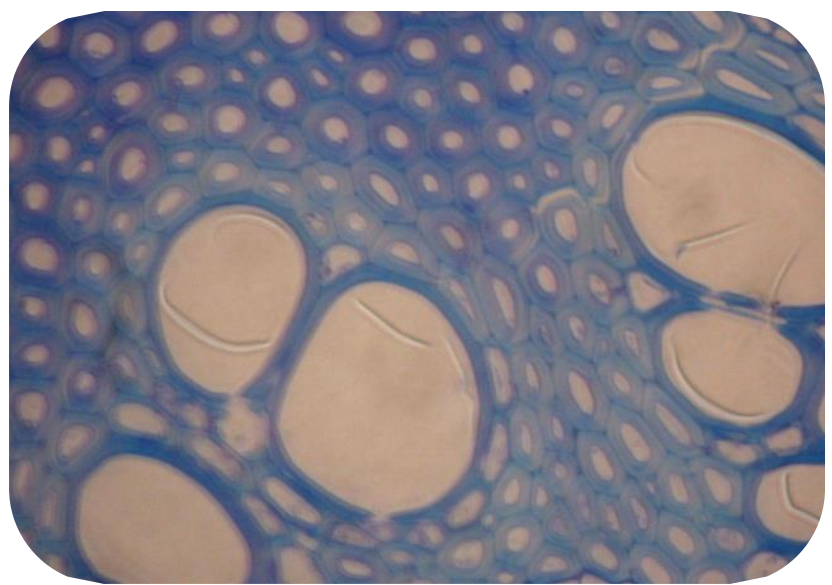

B

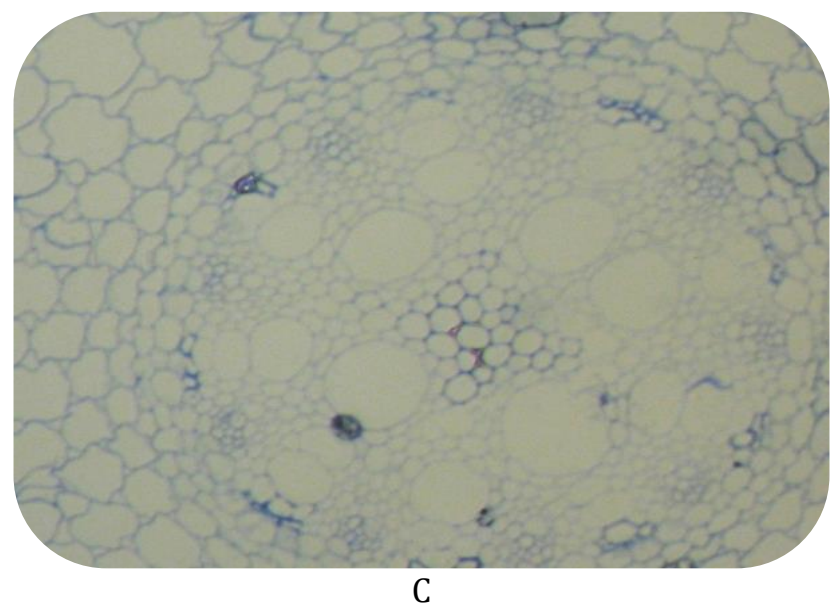

Figure 3 Light micrographs of transverse semi-thin sections of roots of date palm seedling stained with toluidine blue; (a) healthy root . Scale bars $=20 \mu \mathrm{m}$; (b): roots inoculated with Fusarium proliferatum , the macroconidia are observed at the root, in the xylem vessels (xy) xylem. Scale bars $=100 \mu \mathrm{m}$. (c) Tissue of root inoculated with $F$ proliferatum, arrows in (c) locate tyloses (T). Scale bars $=50 \mu \mathrm{m}$.

In order to determine the parts or tissues of the plant that were affected by the pathogen, observations were done on a microscope for the conducting tissues vascular. Occlusions in date palm affected with $F$ proliferatum were recorded, as compared to vessels in healthy plants with no tyloses. Similarly, to our results, data showed that a heavy gum deposition in the xylem vessels of tissues prepared from date palm infected with F proliferatum (Mansoori et al., 2012).

Following vascular infection, host defense responses associated with deposition of gesl, gums and tylosis, and vessel crushing by proliferation of adjacent parenchyma cells (Beckman, 1987).

A study conducted by Bani et al.,(2018) revealed that further colonization of the tissue by $F$ oxysporum $\mathrm{f}$. $\mathrm{sp}$. pisi (Fop) results in necrosis and cellular gums that hastens wilt and death of the pea plant and produces the characteristic brown discoloration of the vascular tissue.

\section{CONCLUSIONS}

Wilt disease of date palm caused by $F$ proliferatum is reported for the first time in Algeria in this study. For this causal agent, Koch's postulates were completed. Morphological characterization in combination with molecular analysis allowed us to identify the $F$. proliferatum responsible for date palm wilt symptoms in Algeria. The disease severity was used to indicate level symptom development in date palm, and they were as high as known Fusarium wilt causal agent as $F$. oxysporum f.sp. albedinis, and the causal agent was reisolated from the inoculated plants. Consequently, the pathogenicity tests on Phoenix dactylifera showed that $F$. proliferatum should be regarded as a potentially dangerous pathogen. Thus, this disease poses a potential threat to the production and biodiversity of date palm, which already has the subject a Bayoud disease.

Finally, the results of this study indicate that $F$. 
proliferatum may be most important pathogens causing wilt of date palm in Algeria, and more attention should be given to the identification of this pathogen.

\section{ACKNOWLEDGMENTS}

The authors express their gratitude to the laboratory of Phytopathology at the department of Biology and Geology, University of Almeria, Spain.

Thanks are due to persons of the Plant Protection Institute of Ghardaia (Institut National de la Protection des Végétaux - INPV)

\section{REFERENCES}

A. A. W. Aletby, M. 2016. First Record of Red Palm weevil, Rhynchophorus ferrugineus (Olivier, 1790) on the Date Palm, Phoenix dactylifera in Basrah, Iraq. Basrah Journal of Agricultural Sciences, 29: 1-6.

Abdalla, M. Y. 2001. Sudden Decline of Date Palm Trees Caused by Erwinia chrysanthemi. Plant Disease, 85: 24-26.

Abdalla, M. Y., A. Al-Rokibah, A. Moretti and G. Mulè. 2000. Pathogenicity of Toxigenic Fusarium proliferatum from Date Palm in Saudi Arabia. Plant Disease, 84: 321-324.

Abdullah, S.K., L.V Lopez Lorca., H.B Jansson.2010. Diseases of date palms (Phoenix dactylifera L.). Basrah J. Date Palm Res, 9:1-44.

Alwahshi, K., E. Saeed, A. Sham, A. Alblooshi, M. Alblooshi, K. El-Tarabily and S. AbuQamar. 2019. Molecular Identification and Disease Management of Date Palm Sudden Decline Syndrome in the United Arab Emirates. International Journal of Molecular Sciences, 20: 923.

Armengol, J., A. Moretti, G. Perrone, A. Vicent, J. A. Bengoechea and J. García-Jiménez. 2005. Identification, incidence and characterization of Fusarium proliferatumon ornamental palms in Spain. European Journal of Plant Pathology, 112: 123-131.

Bani, M., A. Pérez-De-Luque, D. Rubiales and N. Rispail. 2018. Physical and Chemical Barriers in Root Tissues Contribute to Quantitative Resistance to Fusarium oxysporum f. sp. pisi in Pea. Frontiers in Plant Science, 9.

Beckman, C. H. 1987. The nature of wilt diseases of plants. APS press.

Chao, C. T. and R. R. Krueger. 2007. The Date Palm (Phoenix dactylifera L.): Overview of Biology, Uses, and Cultivation. HortScience, 42: 1077-1082.
Djerbi, M. 1998. Diseases of the Date Palm: Present Status and Future Prospects. Journal of Agricultural and Marine Sciences [JAMS], 3: 103.

El Aoufir, A. 2002. Etude du fletrissement vasculaire du pois chiche (Cicer arietinum) cause par le Fusarium oxysporum f. sp. ciceri: Evaluation de la fiabilite de l'analyse isoenzymatique et de la compatibilite vegetative pour la caracterisation des races physiologiques (French text).

Gerlach, W. and H. Nirenberg. 1983. The Genus Fusarium: A Pictorial Atlas. Mycologia, 75: 1110.

Leslie, J. and B. Summerell. 2006. The fusarium laboratory manual. 2006. Ames, Iowa: Blackwell Publishing CrossRef Google Scholar, 388.

Lindner, D. L. and M. T. Banik. 2011. Intragenomic variation in the ITS rDNA region obscures phylogenetic relationships and inflates estimates of operational taxonomic units in genus Laetiporus. Mycologia, 103: 731-740.

Logrieco, A., B. Doko, A. Moretti, S. Frisullo and A. Visconti. 1998. Occurrence of Fumonisin B1and B2 in Fusarium proliferatumInfected Asparagus Plants. Journal of Agricultural and Food Chemistry, 46: 5201-5204.

Louvet,J., J.Bulit. 1972. Le Bayoud, fusariose vasculaire du palmier dattier : Symptômes et nature de la maladie. In : Le palmier dattier et sa fusariose vasculaire (Bayoud),DRA-Maroc, INRA-France.

Luongo, L., A. Ferrarini, A. Haegi, S. Vitale, A. Polverari and A. Belisario. 2014. Genetic Diversity and Pathogenicity of Fusarium oxysporumf.sp. melonisRaces from Different Areas of Italy. Journal of Phytopathology, 163: 73-83.

Mansoori, B. 2012. Fusarium proliferatuminduces gum in xylem vessels as the cause of date bunch fading in iran.

Mansoori, B. and M. H. Kord. 2006. Yellow Death: A Disease of Date Palm in Iran Caused by Fusarium solani. Journal of Phytopathology, 154: 125-127.

Masratul Hawa, M., B. Salleh and Z. Latiffah. 2013. Characterization and pathogenicity of Fusarium proliferatum causing stem rot of Hylocereus polyrhizusin Malaysia. Annals of Applied Biology, 163: 269-280.

Nelson, P. E., T. A. Toussoun and W. Marasas. 1983. Fusarium species: an illustrated manual for identification.

Oechsler, R. A., M. R. Feilmeier, D. R. Ledee, D. Miller, M. 
R. Diaz, M. E. Fini, J. W. Fell and E. C. Alfonso. 2009. Utility of Molecular Sequence Analysis of the ITS rRNA Region for Identification of Fusariumspp. from Ocular Sources. Investigative Opthalmology \& Visual Science, 50: 2230.

Péreau-Leroy, P. and P. Pereau-Leroy. 1958. Le palmier dattier au Maroc. Institut français de recherches fruitiers outre-mer (IFAC) Paris.

Pietro, A. D., M. P. Madrid, Z. Caracuel, J. Delgado-Jarana and M. I. G. Roncero. 2003. Fusarium oxysporum: exploring the molecular arsenal of a vascular wilt fungus. Molecular Plant Pathology, 4: 315-325.

Saaidi, M. 1979. Contribution à la lutte contre le bayoud, fusariose vasculaire du palmier dattier.

Saleh, A. A., A. H. Sharafaddin, M. H. El_Komy, Y. E. Ibrahim, Y. K. Hamad and Y. Y. Molan. 2016. Fusarium species associated with date palm in Saudi Arabia. European Journal of Plant Pathology, 148: 367-377.

Sedra, M. H. 2010. Evaluation of soil receptivity of date palm groves in arab countries to Fusarium oxysporum f. sp. albedinis, causal agent of bayoud disease of date palm. Acta Horticulturae: 515-525.

Seem, R. C. 1984. Disease Incidence and Severity Relationships. Annual Review of Phytopathology,
22: 133-150.

Shahnazi, S., S. Meon, G. Vadamalai, K. Ahmad and N. Nejat. 2012. Morphological and molecular characterization of Fusarium spp. associated with yellowing disease of black pepper (Piper nigrum L.) in Malaysia. Journal of General Plant Pathology, 78: 160-169.

Stępień, Ł., G. Koczyk and A. Waśkiewicz. 2011. Genetic and phenotypic variation of Fusarium proliferatum isolates from different host species. Journal of Applied Genetics, 52: 487-496.

Tamburini, E., E. Mamolini, M. De Bastiani and M. Marchetti. 2016. Quantitative Determination of Fusarium proliferatum Concentration in Intact Garlic Cloves Using Near-Infrared Spectroscopy. Sensors, 16: 1099.

White, T. J., T. Bruns, S. Lee and J. Taylor. 1990. Amplification and direct sequencing of fungal ribosomal rna genes for phylogenetics. PCR Protocols. Elsevier, pp. 315-322.

Zaid, A., P. de Wet, M. Djerbi and A. Oihabi. 2002. In Date palm cultivation, Diseases and pests of date palm, ed Zaid A. Food and Agriculture Organization Plant Production and Protection Paper: 227-281.

\begin{tabular}{|lll|}
\hline Contribution of Authors: & & \\
Safia Sahouli & $:$ & Conduct research and write manuscript \\
Jose Sanchez & $:$ & Reviewed paper critically and improved the manuscript. \\
Eduardo Gallego & $:$ & Data analysis and reviewed the manuscript. \\
Aminata O. E. H. Khelil & $:$ & Reviewed paper critically and improved the manuscript. \\
\hline
\end{tabular}

